\title{
POLITICAL ALLIANCES AND TRADE CONNECTIONS OBSERVED IN THE CERAMIC RECORD OF THE CLASSIC PERIOD: THE PERSPECTIVE FROM THE MAYA SITE OF NAKUM, GUATEMALA
}

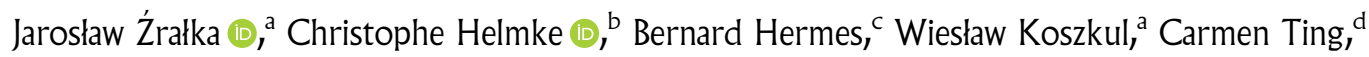 \\ Ronald Bishop, ${ }^{\mathrm{e}}$ and Dorota Bojkowska ${ }^{\mathrm{a}}$ \\ ${ }^{a}$ Institute of Archaeology, Jagiellonian University, Golębia 11 Street, 31-007 Cracow, Poland \\ bepartment of Cross-Cultural and Regional Studies, University of Copenhagen, Karen Blixens Plads 8, 2300 København S, Denmark \\ 'The Nakum Archaeological Project, Peten, Guatemala \\ dMcDonald Institute for Archaeological Research, University of Cambridge, Downing Street, Cambridge, CB2 3ER, United Kingdom \\ ${ }^{\text {eS}}$ Smithsonian Institution of Washington, 10th St., Washington, DC 20560
}

\begin{abstract}
Recent research carried out at the Maya site of Nakum, located in northeastern Guatemala, has brought about the discovery of a large collection of ceramic artefacts. This substantial assemblage, apart from monochrome ceramics, includes fragments of polychrome vessels that are decorated with elaborate iconographic scenes and painted hieroglyphic texts. Most of them date to the Late Classic period (ca. A.D. 600-800), which represents the peak of the pre-Columbian Maya civilization. The style of these ceramics, their iconography and accompanying glyphic texts, supplemented in many cases by mineralogical and physicochemical analyses of the ceramic samples, indicate that Nakum was part of a broad and complex network of political and economic interactions between various sites and polities of the southern Maya lowlands in the Classic period. During the first part of the Late Classic period, Nakum seems to maintain close relations with Naranjo, probably serving as its vassal at least from the reign of its renowned king Aj Wosal. After the victory of Tikal over Naranjo in the first part of the eighth century, Nakum shows closer cultural and political connections with Tikal. Nevertheless, towards the end of the Classic era, when we observe the profound collapse of lowland Maya civilization, Nakum elites gain political independence from their former overlords.
\end{abstract}

\section{INTRODUCTION}

Whereas the vast majority of Maya ceramics are quotidian, unslipped, and plain, made to fulfill a wide range of practical functions, there is one category of ceramics that stands apart from the rest. This particular category is serving vessels, especially those manufactured for the royal court. These serving vessels are distinguished from other ceramics by their surface treatments alone, which are usually highly smoothed and burnished, as well as decorated with a wide array of dazzling colors, detailed patterns, and elaborate iconographic scenes and glyphic texts (e.g., Reents-Budet 1994).

By focusing on these highly decorated ceramics, we are able at times to appraise their motifs, iconography, and glyphs, which together enable us to determine where these ceramics were originally produced and for whom they were intended. Based on present evidence, these ceramics were circulated in a relatively restricted manner, making them an effective proxy to explore the relations and interactions between distinct courts in the Classic period. Royal courts of the ancient Maya were nodes of exchange, where prestigious goods were appraised and traded, but especially

E-mail correspondence to: j.zralka@uj.edu.pl polychrome ceramics to tie and strengthen political, social, and other types of relations (Bishop 2003; Houston et al. 1992; Reents-Budet 1994; Tokovinine 2016). What we explore here are illustrative examples of such relations, which the secondary Maya site of Nakum maintained with different neighboring centers and regions of the northern Peten. As we will show, the ceramic assemblage of Nakum contains vessels whose style, glyphic texts, or chemical composition reveal nonlocal origins and affiliations. As we will try to demonstrate, however, such ceramics may not indicate foreign presence of people but rather the existence of complex interactions between different Maya elites. Many "foreign" ceramics found at Nakum seem to have been bequeathed, inherited, or traded by upper echelons of Maya society to foster alliances of different character. Such valuable objects in most cases were placed to elite burials or caches or used in ritual activities during which they were broken and subsequently scattered in the architectural core of the most distinguished buildings-funerary pyramids and other ceremonial structures.

Our major focus in this paper are the polychromatic and highly decorated ceramics found at Nakum over the course of the last decade of research by the Nakum Archaeological Project of the Jagiellonian University. Iconography backed in many cases by 
petrographic and physicochemical analyses of Late Classic-period Nakum ceramics indicate that this site had very close cultural and possibly also political connections with various neighboring centers, but especially with two principal powers of this region: Naranjo and Tikal.

Our reconstructions are based on both stylistic and archaeometric (petrography and instrumental neutron activation [INAA]) analyses of selected ceramic fragments. Whereas petrographic studies serve to study mineralogical components of ceramic paste and its major temper, INAA enables us to reconstruct chemical composition of ceramic clay that have a direct bearing on the origins of the specimens in question. The latter method has shown a great potential in reconstruction of cultural and political contacts as well long-distance trade of goods between different regions of Mesoamerica (Bishop 2003; Blackman and Bishop 2007; Foias and Bishop 2005; Reents-Budet et al. 2004). The crucial problem, however, remains the comparative data for the analyzed samples. The Nakum samples presented here were compared against the more than 45,000 sherds in a database of Maya pottery thus far analyzed by neutron activation at Smithsonian Institution of Washington as part of the Maya Ceramics Project. The major aim of this project, coordinated by Bishop and Reents-Budet, is to sample and document the chemical composition of pre-Columbian Maya ceramics from many different lowland sites as well as from private and public collections. During the INAA, a final one-to-one search was carried out in which each of the Nakum samples was compared against the substantial sherd database of Maya pottery at Smithsonian Institution of Washington. Using a commonly employed Euclidean distance calculation based on the elemental concentrations with low analytical error, few samples were found that "matched" other pottery at Nakum (previously sampled by Fialko) or at other neighboring Maya sites. This enabled us to seek compositional similarities with various neighboring sites and regions, as well as with other local Nakum ceramics that had been sampled as part of earlier INAA studies.

Although the collection of ceramics presented in this paper is modest and encompasses six samples from vessels or ceramic fragments that were subject to archaeometrical analyses, we selected for these analyses ceramics that clearly stand out of the whole ceramic assemblage of Nakum due to their stylistic attributes and hieroglyphic texts. Based on both INAA and stylistic data, it seems very plausible that the political fortunes of Nakum were initially closely tied to Naranjo, whereas, during the latter part of the Late Classic, after the victory of Tikal over Calakmul in 695, Nakum seems to shift to a more Tikal-centric focus. This is followed, towards the end of the Classic era, with the short-lived independence of Nakum in the face of the collapse of major powers of this region.

\section{NAKUM: SITE SETTING AND CHRONOLOGY}

Nakum is a secondary Maya center located in northeastern Guatemala, in the area of the Yaxha-Nakum-Naranjo National Park. The park encompasses $371 \mathrm{~km}^{2}$ and three major cities of Naranjo, Nakum, and Yaxha, with many other smaller centers also situated in this area (Figure 1). Recently, Nakum has been the subject of archaeological investigations carried out by a team of Polish and Guatemalan scholars between 2006 and 2017. This, as well as previous research conducted by the Instituto de Antropología e Historia, reveals that Nakum was first settled during the Middle Preclassic period (1000/900-300 B.C.), but experienced its apogee in the Classic era, especially during the Late and Terminal Classic (A.D. 550/600-900/950). One of the most interesting developments in the history of this site is its anomalous growth towards the end of the Classic period - the ninth and the beginning of the tenth centuries-a time that is otherwise characterized by a profound crisis and collapse of most lowland Maya centers. Nonetheless, during this time, Nakum witnessed major architectural programs and its lords commissioned the largest number of carved monuments documented to date at the site (Helmke et al. 2018; Źrałka and Hermes 2012).

Nakum consists of two major parts denominated the North and South Sectors that are connected by an elevated causeway (Périgny Causeway), which is $250 \mathrm{~m}$ long and $25 \mathrm{~m}$ wide. These two major sectors are formed by monumental architectural constructions featuring pyramidal temples, palaces, and buildings serving many other functions, most of them arranged around plazas. The largest and most impressive part of the site is the Southern Sector, where we see concentration of the tallest buildings; most pyramids are located here. Additionally the enormous Acropolis, consisting of a large platform topped by more than 60 structures (most of them residential and administrative constructions) arranged around courtyards, is also located here. It has been argued (Źrałka and Hermes 2012:168-169) that the seat of a royal dynasty during the Terminal Classic period (A.D. 800-900/950) was located in the hearth of the Acropolis (in the area of complex denominated Central Acropolis).

Since the subject of borders is one of the major themes of this Special Section, it must be stressed that Nakum was located in a very dynamic geopolitical zone. It is situated equidistantly between Tikal and Naranjo (approximately 22 kilometers from Tikal and 16 kilometers from Naranjo), two central polities that became staunch antagonists during the Classic period (Martin and Grube 2000). Naranjo, as a key vassal of the Snake or Kanul dynasty, became a natural enemy of Tikal under the long reign of the Naranjo king that is referred to in the epigraphic literature as Aj Wosal (regnal years: A.D. 546-ca. 615). Nakum was located in a region that could be described as a buffer zone, where the political interests of these two powerful kingdoms conflicted and clashed. As for now, no major fortifications marking the frontiers of these kingdoms have been documented in this area. We should remember, however, that although physical borders are known in the Maya area in such centers and regions as Tikal, Becan, the Pasión Region, and the Usumacinta (Demarest et al. 1997; Puleston and Callender 1967; Scherer and Golden 2009; Webster et al. 2007; see also Canuto et al. [2018] for defensive systems revealed by the PACUNAM LiDAR Initiative in northern Guatemala), in general Mesoamerica is characterized by the existence of what we may call "open borders." These are unmarked borders with open borderlines that usually align to natural features such as rivers, mountains, lakes or forests (Helmke et al. 2019a; Trigger 2003). In this context, we should mention that the vast bajo La Justa could have served precisely as such a natural border, disabling ingress of warring parties as well as other groups.

The bajo La Justa is a seasonal swamp located between Nakum and Yaxha, covering the area of $150 \mathrm{~km}^{2}$. The existence of architecture was confirmed within elevated parts of the bajo during previous research carried out by Culbert (Culbert et al. 1997), Fialko (2005), and other scholars (Kunen et al. 2000). Contrarily, there were no traces of settlements documented in the low-lying areas, as they were exposed to repeated flooding in the rainy season. During these periods, bajos become marshy thickets that are greatly difficult to cross (Kunen et al. 2000:17, 21). Likewise, various scholars (Carr 


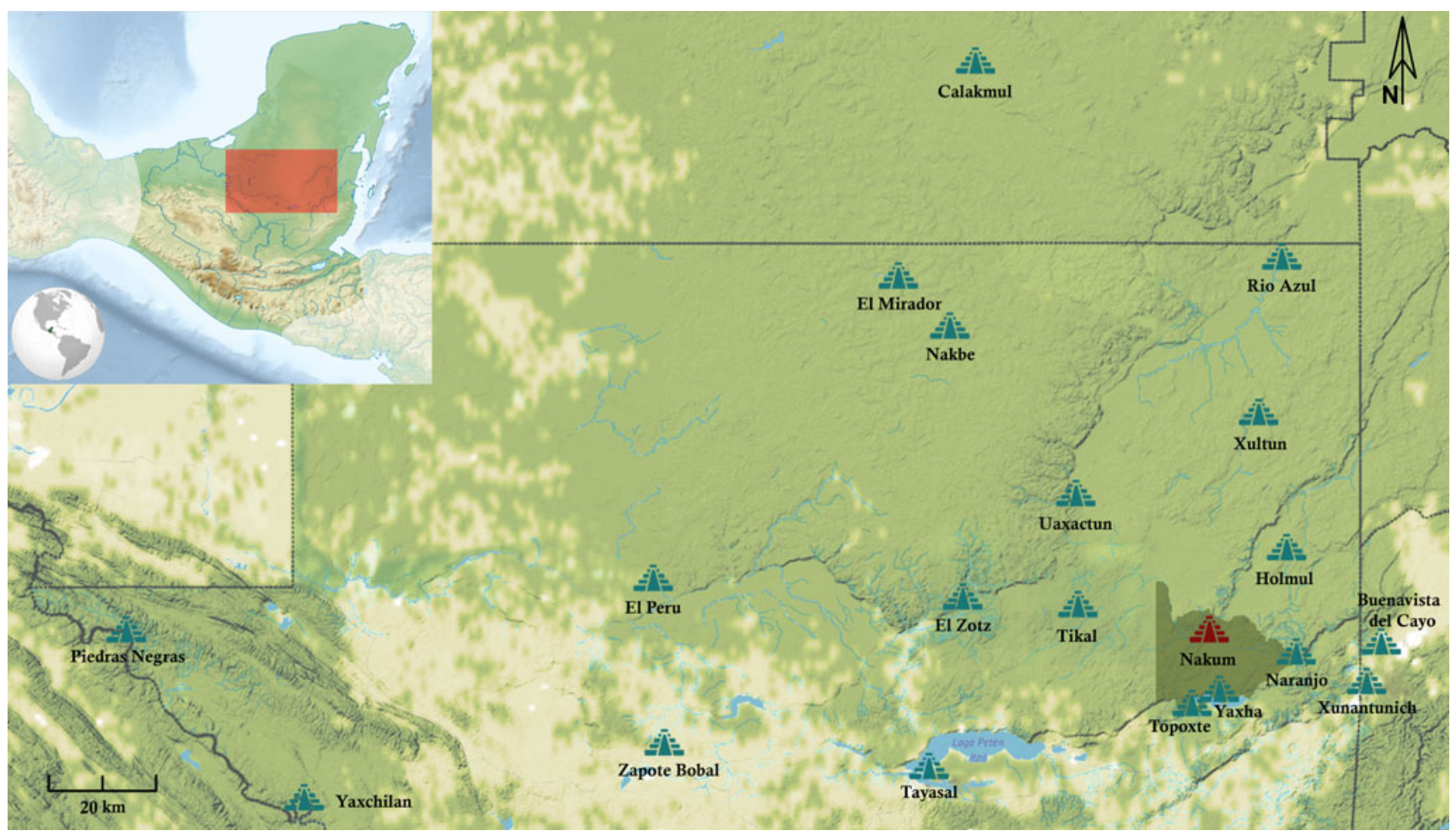

Figure 1. Map of northern Peten and surrounding areas with location of Yaxha-Nakum-Naranjo National Park, and most dominant sites of the region. Map by Bojkowska.

and Hazard 1961:9; Haviland 1981:89; Puleston and Callender 1967:41-47) have suggested that the bajos located close to Tikal formed natural boundary of this center. In addition, artificial earthworks were constructed to the north, south and west of Tikal between the bajos, presumably to demarcate the city from each side (Garrison et al. 2019; Haviland 1981:89; Webster et al. 2007). Bajo La Justa, could also be considered as a natural boundary between Naranjo and Tikal, and perhaps is the reason Nakum was located in that area as a border city.

\section{EARLY CLASSIC AND TEOTIHUACAN TIES}

Before we move to the major topic of our paper, that of Late and Terminal Classic ceramics and their exchange, it is worth mentioning the subject of cultural and political affiliations of Nakum during the first part of the Classic period. The famous entrada event that took place in A.D. 378 and was followed by a series of incursions and conquests in the Guatemalan Peten (Stuart 2000) undoubtedly had a serious impact on Nakum and neighboring Yaxha. Although we do not have direct epigraphic evidence to support this claim, one carved monument at Yaxha (Stela 11) depicts a personage in Teotihuacan attire-most likely Sihyaj K'ahk' himself or one of his lieutenants (Grube 2000:255). This incursion, however, seems to be a very brief one, as we find almost no archaeological evidence of Teotihuacan contacts at Yaxha in terms of ceramics and architecture. That said, Yaxha has very sparse Early Classic architectural activity. Nakum, however, has an interesting complex consisting of four connected talud-tablero platforms enclosing a large plaza (Patio 1; Koszkul et al. 2006). In terms of its architectural layout, the complex finds its closest counterparts in Teotihuacan itself. Recent excavations of one of these platforms
(Structure G Sub-3 enclosing Patio 1 from the south) produced in its core numerous artefacts of Teotihuacan affiliation, including fragments of floreros, tripod cylinder vases with slab feet, and green obsidian (projectile points, blades, and other artefacts; Figure 2). These artefacts belong to the so-called Nayes ceramic complex, which is the local equivalent of Tzakol Horizon, and specifically of its latter facets (Tzakol 2-3; Hermes 2019). Besides, recent analysis of the oxygen isotopes of a sub-adult tooth recovered from the fill of the talud-tablero platform $\mathrm{G}$ Sub-3 shows nonlocal $\delta^{18} \mathrm{O}$ value, which are in the range of central Mexico. Since the enamel of the tooth forms in utero, the nonlocal value of the sample reflects migration of this individual's mother to the Peten, most probably from central Mexico though other areas such as Guatemalan Highlands, southwestern Mexico, or the Pacific Coast cannot be excluded on the basis of very similar low $\delta^{18} \mathrm{O}$ values (Rand et al. 2020). Several radiocarbon samples from the core of the latter construction produced dates that indicate the whole complex most probably postdates the entrada events. In our opinion, a Teotihuacan-related order might have been established in this region via Tikal. In the Triangle Park area, this would have included at least Yaxha and Nakum, the two centers that might have been under the political influence of Tikal both before, as well as after the entrada.

\section{MIDDLE CLASSIC AND CONNECTIONS WITH NARANJO}

Available archaeological data indicate that during the initial part of the Late Classic period, Nakum's political fortunes were tied to Naranjo, a powerful center located just $16 \mathrm{~km}$ southeast of Nakum. Such ties were most probably established during the 

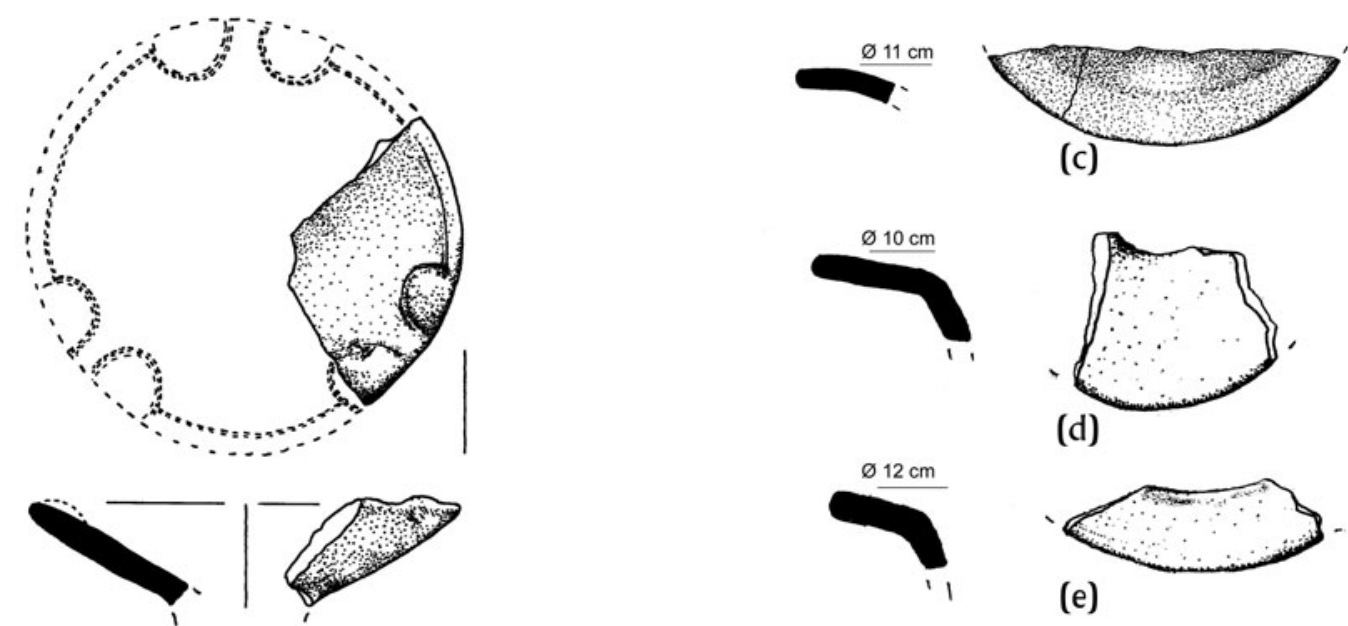

(d)
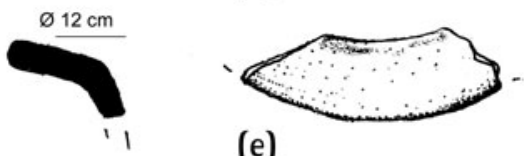

(e)

(a)
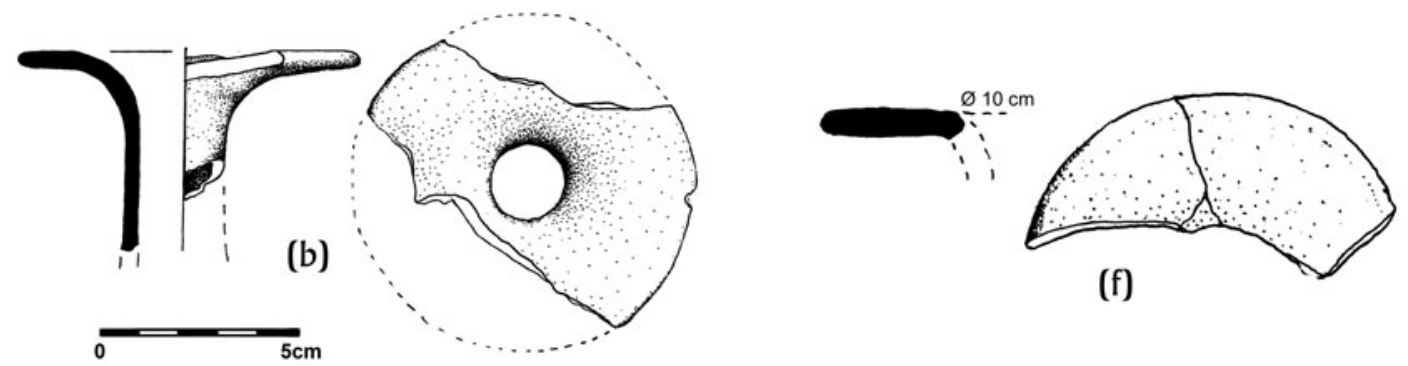

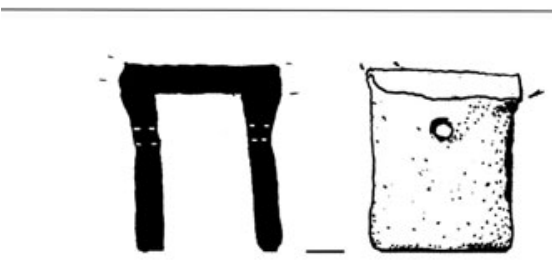

(g)

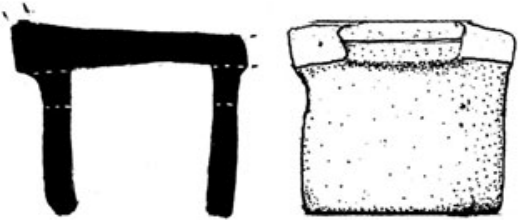

(h)

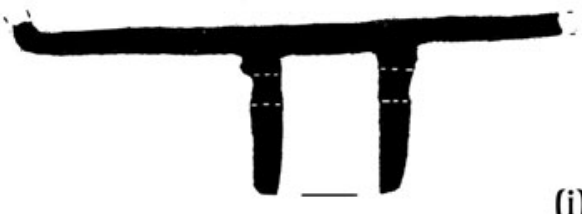

(i)
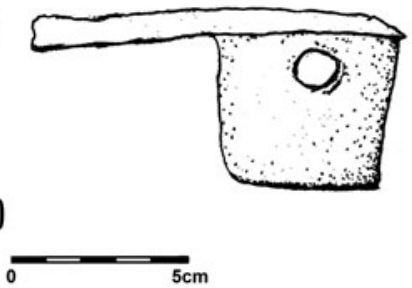

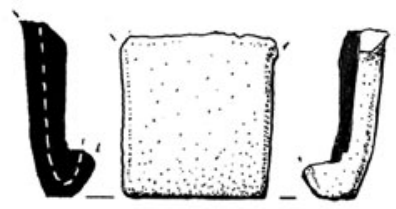

(j)

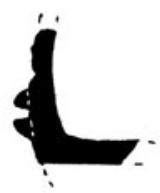

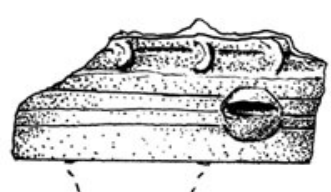

(k)

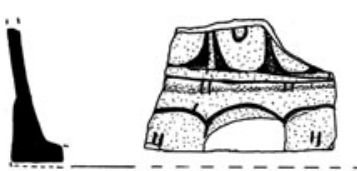

(I)

Figure 2. Examples of ceramic artefacts of Teotihuacan affiliation found at Nakum: (a-f) fragments of floreros and ( $\mathrm{g}-\mathrm{l}$ ) tripod cylinder vases with slab feet. Drawings by Piotr Kolodziejczyk.

reign of one of Naranjo's most famous and powerful lords, Aj Wosal (Martin and Grube 2000:71-72). Several vessel fragments found at Nakum show clear stylistic links to the ceramics produced under the patronage of this Naranjo king.
The first is the rim of a cylindrical vessel found in the core of Structure 14 that borders Patio 1 on the southeast (Figure 3a, Table 1). This structure played a prominent role in the religious and social life of Nakum, serving as one of the major temples, 

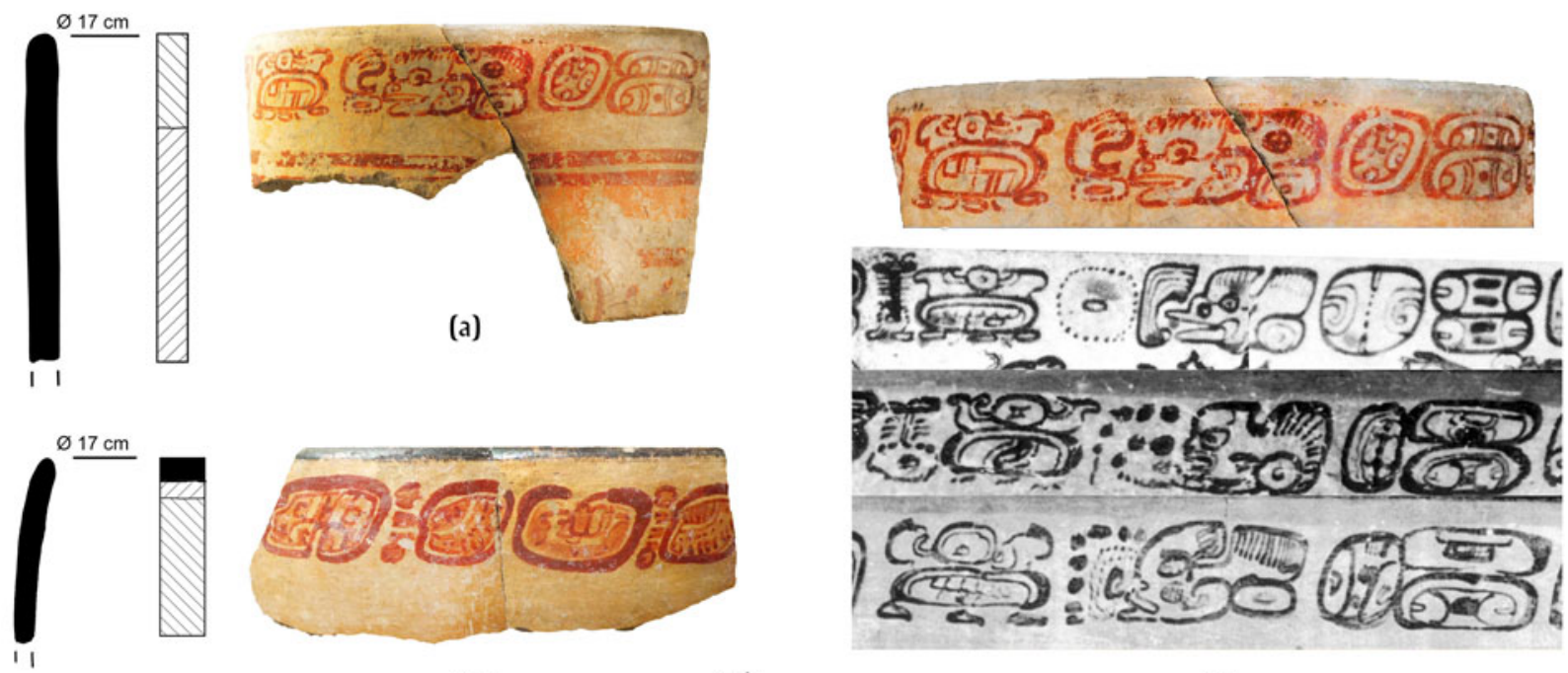

(b)

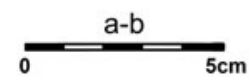

(c)

Figure 3. ( $a$ and b) Two vessel fragments found within the core of Structure 14 and exhibiting paleographic affiliations to the ceramic workshops patronized by Aj Wosal, the great king of Naranjo. (a) Palmar Orange Polychrome. (b) Saxche Orange Polychrome. Photographs by Robert Słaboński. (c) Examples of very similar ceramic vessels (Kerr Nos. K1558, K2704, and K5042) produced for Aj Wosal. Details of photographs by Justin Kerr.

which for at least some part of its existence served as a provisional burial place where esteemed individuals might have been located before the final burial took place (Źrałka and Koszkul 2015). Many beautiful vessels, including the examples described in this paper, were deposited in its core in what must have been ceremonial activity related to the rebuilding and expansion of this construction. The preserved fragment's exterior is decorated with red-painted glyphs along the rim. The text refers to the content of the vase, and the ownership. The contents, as preserved, is written yutal ka[kaw], or "[for] fruity kakaw," followed by CHAK-ch'o-ko, for chak ch'ok, or "great youth."

Although the name of the owner is not preserved, there are a series of paleographic features that suggest links between this specimen and those of Naranjo. In fact, the glyphs of these vessels can be compared to the analogous contents and titular sections of the vessels produced for Naranjo's Aj Wosal. Close comparisons can be drawn with at least three of the vessels of Aj Wosal including K1558, K2704, and K5042 (Figure 3c; Kerr 2019). In each of these cases, the same type of dedicatory inscription is visible. These glyphs are distinctive enough to imply that, while these vessels might not have been produced by the same scribe, they certainly belonged to the same scribal milieu. That being said, recent INAA of this specimen shows that it has the strongest links with local Nakum ceramics. This may indicate that it was manufactured at Nakum or at a local workshop either patronized by the Naranjo court or its artisans, or alternatively is a local production emulating a Naranjo style. The form of the vessel is more vase-like and thereby suggests that it dates either to the end, or shortly after, the reign of Aj Wosal, a typological attribute that may speak in favor of local emulation.

A second fragment equally suggests links to Aj Wosal's ceramic workshop based on its paleography. The fragment in question comes from a Saxche Orange Polychrome type bowl and it features a fragment of text of the PSS (Primary Standard Sequence) series (Figure 3b). The glyphs are very similar to the glyphic texts from the vessels such as K4958, K2704, K4562, or K5042, all of which belong to Aj Wosal's ceramic workshops and mention his name. The latter fragment has been also found in the core of the aforementioned Structure 14.

One more example that betrays links with Naranjo under the reign of Aj Wosal is another ceramic bowl of the Saxche Orange Polychrome type (vessel PANFC 025; Figures 4a-4d), which is very similar to the fragment just described. In this case, however, it is the iconography that is more revealing. The long and slender linear elements together may form the stylized beak of a hummingbird. The main diagnostic element of a hummingbird in Maya iconography is the flower that adorns its elongated beak, or bill, as though the flower and bird are interdependent in generating meaning in Maya thought and representational conventions. In this context, we should mention a vessel, which is now in the collections of the Museo del Vidrio in the Hotel Santo Domingo in La Antigua, Guatemala (Luin et al. 2018:879, Figure 3). The iconography on this bowl is dominated by a kneeling male figure who braces a large ceremonial bar (Figure 4e). The text along the rim confirms that this was once owned by none other than $\mathrm{Aj}$ Wosal. The connection to Naranjo, as expressed on this vase, is more profound, since one of the major tutelary deities of the dynasty was a hummingbird deity, or better said, the hummingbird aspect of a feline entity in anthropomorphic form (Helmke et al. 2019b:20-21, 23, 25). Recent excavations at Naranjo, conducted by Vilma Fialko, have revealed a palace building named Aurora, located within the so-called Central Acropolis complex that is embellished by hummingbirds and depictions of this hummingbird deity in relation to a sacred florid mountain. The latter structure was part of a royal palace complex of Aj Wosal, and its decoration further confirms the centrality of this supernatural being in local myths and historical narratives (Tokovinine and Fialko 2019).

Another vessel fragment found on island of Paxte on lake Yaxha, just $11 \mathrm{~km}$ to the south of Nakum, represents a very similar anthropomorphic figure; a long projection emanates from his nose, which likewise appears to perforate a florid element (Figure 4f; Hermes 2000:Figure 141:3). 
Table 1. List of ceramic fragments mentioned in the text that were subject of instrumental neutron activation analysis (INAA) and petrographic analyses.

\begin{tabular}{|c|c|c|c|c|c|}
\hline $\begin{array}{l}\text { The Nakum Archaeological } \\
\text { Project Sample Number and } \\
\text { Provenience }\end{array}$ & $\begin{array}{l}\text { Smithsonian } \\
\text { Institution Lab } \\
\text { Number }\end{array}$ & Ceramic Type & INAA Results & Petrographic Analysis Results & $\begin{array}{l}\text { Illustration } \\
\text { Number in } \\
\text { the Text }\end{array}$ \\
\hline $\begin{array}{l}\text { Sample 1, core of Structure } 14 \\
\text { (VI-16-1) }\end{array}$ & NKM038 & $\begin{array}{l}\text { Palmar Orange } \\
\text { Polychrome? or } \\
\text { Saxche Orange } \\
\text { Polychrome }\end{array}$ & $\begin{array}{l}\text { Strongest links with other } \\
\text { Nakum ceramics. }\end{array}$ & $\begin{array}{l}\text { Sample was not subject of } \\
\text { petrographic analysis due to its } \\
\text { small size. }\end{array}$ & Figure $3 \mathrm{a}$ \\
\hline $\begin{array}{l}\text { Sample } 2 \text {, midden on the eastern } \\
\text { side of Acropolis complex } \\
\text { (XI-1-3-4) }\end{array}$ & NKM039 & $\begin{array}{l}\text { Naranjal } \\
\text { Red-on-Cream }\end{array}$ & $\begin{array}{l}\text { Very few "matches" but } \\
\text { two from Naranjo, no } \\
\text { links to Tikal or the } \\
\text { general Peten Lakes } \\
\text { region. }\end{array}$ & $\begin{array}{l}\text { Ceramic paste made of very } \\
\text { angular volcanic ash with } \\
\text { biotite, plagioclase, and quartz } \\
\text { in the matrix; the ceramic body } \\
\text { covered with a thick layer of } \\
\text { slip made of calcareous clay, } \\
\text { followed by paint. }\end{array}$ & Figure $5 \mathrm{a}$ \\
\hline $\begin{array}{l}\text { Sample 3, part of vessel no. } \\
\text { PANFC 025, core of Structure } 14 \\
\text { (VI-21-4-1b) }\end{array}$ & NKM040 & $\begin{array}{l}\text { Saxche Orange } \\
\text { Polychrome }\end{array}$ & $\begin{array}{l}\text { Weak links with pottery } \\
\text { from Yaxha. }\end{array}$ & $\begin{array}{l}\text { Made of a fabric, which } \\
\text { contains only calcite, the } \\
\text { ceramic body of the vessel } \\
\text { covered with a thick layer of } \\
\text { slip made of calcareous clay, } \\
\text { followed by paint. }\end{array}$ & Figures $4 a-4 d$ \\
\hline $\begin{array}{l}\text { Sample 4, part of vessel no. } \\
\text { PANFC } 031 \text {, floor of the Eastern } \\
\text { Chamber of the temple located on } \\
\text { top of Pyramid X, part of } \\
\text { termination or veneration rituals } \\
\text { (I-6A-13) }\end{array}$ & NKM041 & $\begin{array}{l}\text { Granja Central } \\
\text { Compuesto }\end{array}$ & $\begin{array}{l}\text { Likely Naranjo-several } \\
\text { matches with pottery that } \\
\text { are considered the core } \\
\text { Naranjo composition. }\end{array}$ & $\begin{array}{l}\text { Sample has volcanic ash temper } \\
\text { with only a few other inclusions } \\
\text { in the fabric presented. The } \\
\text { paint was applied directly to the } \\
\text { surface of the vessel, without } \\
\text { any slip layer underneath. }\end{array}$ & Figure $10 \mathrm{a}$ \\
\hline $\begin{array}{l}\text { Sample 5, part of vessel no. } \\
\text { PANFC 032, core of Structure } 14 \\
\text { (VI-21-6-2) }\end{array}$ & NKM042 & $\begin{array}{l}\text { Saxche Orange } \\
\text { Polychrome }\end{array}$ & $\begin{array}{l}\text { Greater Tikal region (site } \\
\text { and periphery), likely a } \\
\text { Tikal dancer plate. }\end{array}$ & $\begin{array}{l}\text { Made of a fabric that contains } \\
\text { only calcite. The ceramic body } \\
\text { of the vessel is covered with a } \\
\text { thick layer of slip made of } \\
\text { calcareous clay, followed by } \\
\text { paint. }\end{array}$ & Figure 8 \\
\hline $\begin{array}{l}\text { Sample 6, part of vessel no. } \\
\text { PANFC 033, core of Structure G } \\
\text { (VI-31A-8) }\end{array}$ & NKM043 & $\begin{array}{l}\text { Palmar Orange } \\
\text { Polychrome }\end{array}$ & $\begin{array}{l}\text { Likely from the } \\
\text { Nakum-Yaxha area. }\end{array}$ & $\begin{array}{l}\text { Ceramic paste made of very } \\
\text { angular volcanic ash with } \\
\text { biotite, plagioclase, and quartz } \\
\text { in the matrix. The ceramic body } \\
\text { covered with a thick layer of } \\
\text { slip made of calcareous clay, } \\
\text { followed by paint. }\end{array}$ & Figure $10 \mathrm{~b}$ \\
\hline
\end{tabular}

Together, these vessels are essentially identical to the vase that Estrada-Belli (2018) recently uncovered in one of the burials located in Holmul Structure D. The latter vessel depicts an individual in a hummingbird mask, and its text equally identifies its owner as $\mathrm{Aj}$ Wosal, indicating it was bestowed to a local Holmul king as a special gift (Estrada-Belli 2018:10-11).

Although highly stylized, the schematic beak of the hummingbird, penetrating the characteristic flower on the Nakum vessel, together may serve to cue the tutelary deity of Naranjo, which along with the other stylistic features of the bowl, once again point to a period, or at least an episode, of close contact with Naranjo, during the late sixth and early seventh century.

All the above-described vessels reveal close connections between Nakum and Naranjo at this relatively early date, with Naranjo presumably in dominant position and Nakum in subservience. This provides the impression of a strong and regionally dominant Naranjo during the reign of Aj Wosal, and all the evidence present certainly points to this as the prevailing picture. This situation is similar to what we observe in many other contemporaneous Maya sites of the eastern Peten (e.g., Holmul) and western Belize which were under a strong influence and political control of Naranjo (Estrada-Belli 2018; Estrada-Belli and Tokovinine 2016; Helmke and Awe 2008:79-84).

\section{LATE CLASSIC RELATIONS WITH TIKAL}

One of the hallmarks of the eastern central lowlands are the finely painted ceramic vessels bearing the so-called Holmul Dancer scenes, named after the type specimen encountered at that site in 1911. The imagery on these vessels is typically painted in dark red outlines, with diluted orange wash applied sparingly to define figurative elements in the foreground. These stand out on the neat cream backgrounds that define the ceramics of this type. Primary emphasis of the Holmul Dancer scenes is placed on the Maize god, represented dancing in majesty, bearing intricate regalia, and often assisted by a dwarf. These scenes are interpreted as representing a pivotal moment in the mythic narrative of the Maize god: his resurrection from the Underworld (Helmke 2019; Houston et al. 1992; Reents-Budet 1991). 

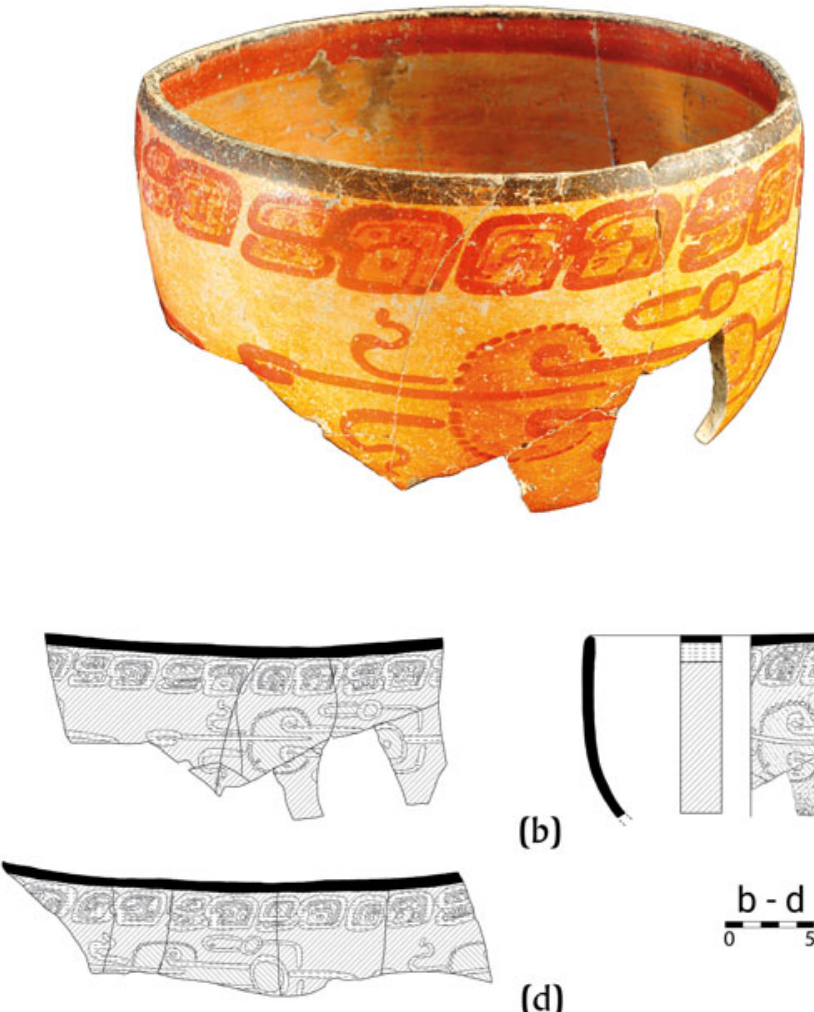

(b)

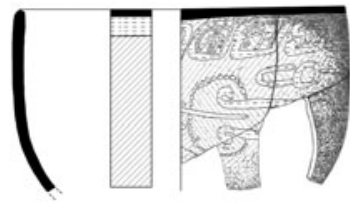

(c)

$$
\frac{b-d}{5}-\frac{d m}{0}
$$

(d)

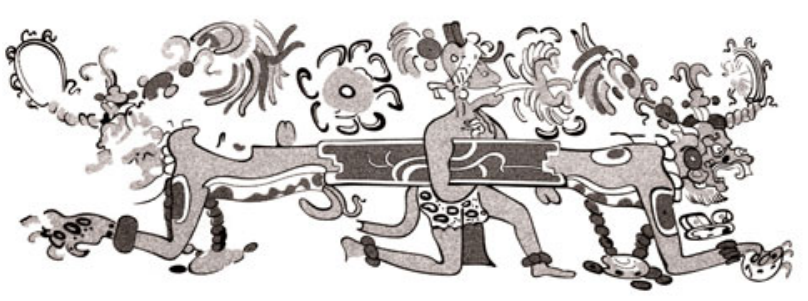

(e)

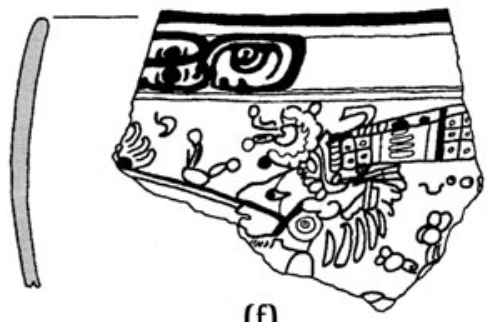

(f)

Figure 4. (a-d) Ceramic bowl decorated with pseudoglyphs and stylized representation of a hummingbird beak. Vessel PANFC 025 of Saxche Orange Polychrome type. Photograph by Robert Słaboński, drawings by Katarzyna Radnicka. Other representations of hummingbird deity: (e) the vessel from the collection of Museo del Vidrio in the Hotel Santo Domingo in Antigua Guatemala (drawing courtesy of Filipp Galeev) and (f) from a bowl excavated at Paxte (after Hermes 2000:Figure 141:3).

The themes of the Holmul Dancer vessels were of great significance to the sites of the eastern central lowlands, with Naranjo, Holmul, Xultun, and Río Azul distinguishing themselves as key production centers of this type of ceramic (Helmke 2019: 125-139; Reents-Budet 1994:179-185, 294-305). The rim texts of these vessels include the standard dedicatory formula and prominently name their original owners. For Naranjo, these were owned gby the seventh century king K'ahk' Tiliiw Chan Chaahk (regnal years: A.D. 693-728+) who was a patron of the production of many such vessels (Martin and Grube 2000:74-77).

The discovery at Nakum of a rim sherd of the vessel of such style (Figure 5a) is not particularly surprising per se, given the proximity to Naranjo, one of the major production centers of ceramics of this group. What is remarkable, however, is that the name of the owner of that vase is preserved, and that it names a king of Tikal. The reference is made through the well-known royal emblem glyph of the kings of Tikal, written K'UH-MUT-AJAW for $k^{\prime} u h[u l] m u t\left[u^{\prime} l\right]$ ajaw, or "godly Mutu'l king," a title built on the toponym of the ancient metropolis.

Since Tikal is not known as a production center of Holmul Dancer ceramics, we are inclined to conclude that this vessel was most probably produced at an established workshop, given the quality of the line work and ceramic generally, and crafted as a bespoke vase, made specifically to be given to a lord of Tikal as a sign of thanks and gratitude. It is quite possible that the fragment in question comes from a vase made specifically for a king of Tikal in one of the royal workshops of Naranjo. This observation may be further supported by results of the INAA analysis, which show some connections with Naranjo region (or at least the greater Holmul region) in terms of the chemical composition of the paste but no links to Tikal or the greater Peten Lakes region. Petrographic analysis of this vessel shows that a volcanic ash-tempered ceramic paste 

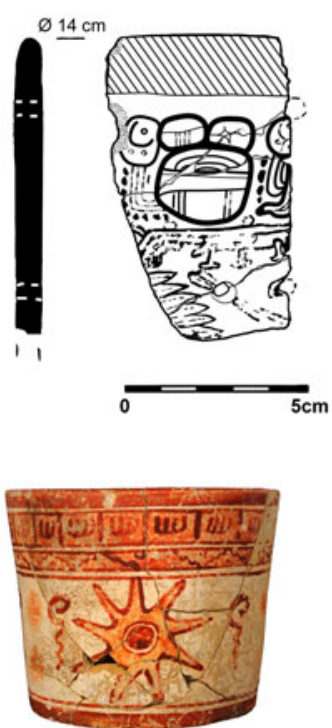

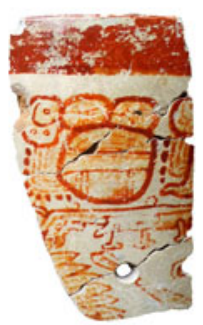

(a)
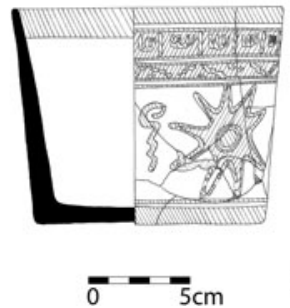

(b)
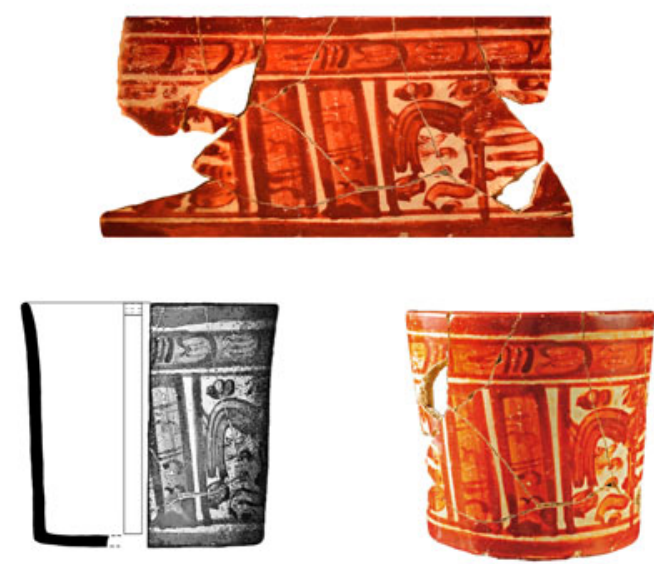

$\overline{0}-\overline{5} \mathrm{~cm}$

(c)

Figure 5. Ceramics of the Holmul Dancer style or of similar stylistic affiliation documented at Nakum. (a) Ceramic rim with text mentioning Tikal Emblem Glyph (Naranjal Red-on-Cream). (b) Nakum vessel PANC 009 (Zacatal Cream Polychrome?). (c) Vessel PANFC 035 found in Nakum Burial 11 (Naranjal Red-on-Cream). Photographs by Robert Słaboński and Źrałka, drawings by Bojkowska.

was used (Figure 6a), which is common among the polychrome vessels that were produced during this time period.

The question is how did this vase make its way to Nakum? According to one hypothesis, it might have been secondarily gifted by the Tikal king to one of the Nakum lords to cement ties between Tikal and its lesser neighbor to the east. These critical questions cannot be resolved at present based on the data available, yet this single sherd highlights a highly dynamic period of intrasite interactions and allegiances, which has not yet been fully appreciated.

As an analogy to our Nakum find, we can mention the so-called Cormorant Vase described by Reents-Budet (1994:300-301) in her famous book on painted Maya ceramics. Although the exact provenience of the Cormorant Vase is unknown, its chemical profile and style indicate that it was produced in Naranjo under the patronage of K'ahk' Tiliiw Chan Chaahk. The PSS text of this vessel, however, ends with the name of the Ucanal king, "Itzamnaaj" Bahlam, as its owner. It seems then that the vessel might have been commissioned by the Naranjo king to be made for the ruler of Ucanal, possibly to cement political alliances between these two cities (Helmke et al. 2017:19-21; Reents-Budet 1994:300-305). The famous discovery of a Holmul Dancer vase (called Jauncy Vase) of K'ahk' Tiliiw Chan Chaahk, deposited in a tomb of Buenavista del Cayo lord might also be recalled here (Taschek and Ball 1992). The paste composition combined with paleographic features of the Jauncy Vase and the Cormorant Vase indicate that they both might have been manufactured at the same workshop attached to Naranjo court during the reign of K'ahk' Tiliiw Chan Chaahk (Helmke et al. 2017:11). The latter examples show how this famous Naranjo king was known from giving/gifting vessels, both ceramics that name him as owner, as well as those produced in his workshops but naming other lords with whom K'ahk' Tiliiw Chan Chaahk wanted to keep special political and cultural relations. The Nakum fragment described above fits this model although available data (INAA backed by epigraphic and stylistic analysis as well as archaeological context of the find) indicate secondary gifting from Naranjo to Tikal and then to Nakum.

Another interesting vessel from Nakum that shows links with the Holmul-style pottery is a cylindrical vase, $13.8 \mathrm{~cm}$ high, of the Naranjal Red-on-Cream type (PANFC 035; Figure 5c). It was recently found in a grave (Burial 11), placed within a notable residential group situated on the periphery of the site (Structure 229 of Patio 52) but very close to the epicenter, and most probably inhabited by a leading noble family. It is very similar to the Holmul-style pottery, especially to the vessels of Cabrito Cream Polychrome from Buenavista del Cayo or Baking Pot, which were two prominent production centers of this ceramic style. The Nakum example, similar to its Belize counterparts, is characterized by lesser quality painting and lack of legible PSS texts. It should be also stressed that fragments of a similar ceramic type have also been discovered in several other locations of epicentral Nakum. In addition, one completely preserved vessel (PANC 009) is very similar in its form and design to Holmul-style pottery, which features a star motif painted in red outlines and an orange interior on a cream background (Figure 5b).

\section{SOME FURTHER COROLLARIES: TO THE WEST AND EAST}

That Nakum maintained close relations with Tikal is made evident by other ceramic finds made at Nakum. For instance, the wellknown Tikal Dancer plates, typical for the Tikal region, are in essence just local adaptations, equally representing the Maize god dancing out of the Underworld at his resurrection (Boot 2003; Reents-Budet 1994:197-198). One such Tikal Dancer plate (vessel PANC 002; Figure 7) was found in a particularly wellfurnished royal tomb (Burial 1), excavated within Structure 15 in the Acropolis of Nakum, and dated to around A.D. 700 (Hermes 2019:432). The individual buried in that tomb was evidently a distinguished figure at Nakum, given the value of the materials found, 


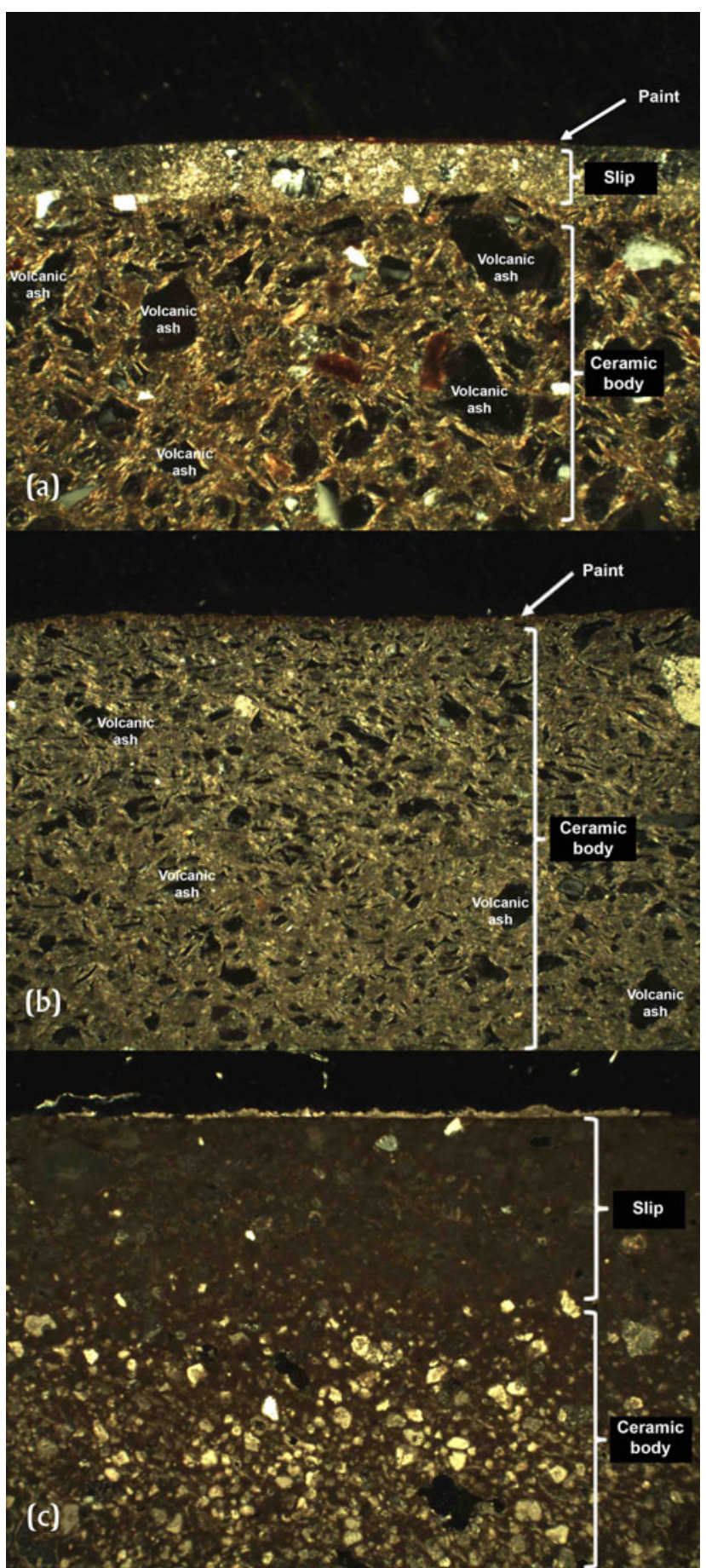

Figure 6. Photomicrographs of the thin sections of three polychrome ceramic fragments from Nakum featuring different temper. (a) Sample 2 from vessel shown in Figure 5a. Ceramic paste was made of very angular volcanic ash with biotite, plagioclase, and quartz in the matrix and the ceramic body was covered with a thick layer of slip made of calcareous clay, followed by paint. (b) Sample 4 from vessel PANFC 031, shown in Figure 10a. Ceramic paste has volcanic ash temper with only a few other inclusions in the fabric presented. The paint was applied directly to the surface of the vessel, without any slip layer underneath. (c) Sample 5 from vessel PANFC 032, shown in Figure 8. Paste was made of a fabric that contains only calcite and the ceramic body of the vessel was covered with a thick layer of slip made of calcareous clay, followed by paint. including a rich array of jade jewels, three vessels, spindle whorls, and other artefacts. Among the many items of personal adornment was a large, carved, and inscribed early jadeite pectoral, clearly an heirloom, dating to the Protoclassic or beginning of the Classic period (Źrałka et al. 2011).

Related to the above is another Saxche Orange Polychrome (PANFC 032) plate, of which only two fragments have survived (Figure 8). The plate was found broken into pieces in the core of Structure 14. Based on the size of these fragments, the plate was likely $41 \mathrm{~cm}$ in diameter. The INAA results designate the plate for the greater Tikal region, both the site and its periphery. The preserved elements of the iconography indicate that it once represented an individual in a dancing position. Consequently, based on the INAA results and its iconography, this vessel was most likely another example of a Tikal Dancer plate produced in the greater Tikal region. What merits special attention here are the glyphs decorating the rim of the plate. Apart from two regnal names, we find a fragmentarily preserved glyph that consists of a comb sign preceding a main sign representing a male profile, which may serve as part of a title. At present, the precise identity of this glyph is unclear, but the regnal names can be partially made out as K'ahk' Pitay and Mo' Yopat, undoubtedly naming the original owner of the plate. Based on present evidence we cannot tie in this name to any other known regnal name, at either Nakum or abroad, but we are inclined to see this as foreign reference and thereby an import to the site.

It is during the late seventh century that we see a profusion of another group of Zacatal Cream-polychrome ceramics, decorated with the "Dress Shirt" design, so named because of its apparent similarity to a freshly-laundered dress shirt. Yet, a more in-depth analysis of this motif reveals that it is in fact the distinctive feathers of the quasi-supernatural muwaan bird. The rich ceramic assemblage found in the tomb of the renowned Tikal king, Jasaw Chan K'awiil I, beneath the archetypal Temple I, includes several Zacatel vessels, decorated in precisely this fashion (Culbert 1993: Figures 91-96), and may point to Jasaw Chan K'awiil as the originator of this motif and ceramic type, which also became very popular during the reign of his successors. Ceramics of this type were found in an impressive assemblage within a chultun excavated by Tozzer (1913:188-190) at the beginning of twentieth century and at several other locations at Nakum (Figure 9). One of the vessels was fashioned in a series of stacked tiers, as seen in Figure $9 \mathrm{~b}$. The presence of such ceramics at Nakum, thereby, further highlights close relations with Tikal during the reign of this late seventh century king.

\section{RELATIONS TO THE CENTRAL PETEN}

Other ceramics found at Nakum also reveal the relations with neighboring sites and with the central Peten as a whole during Tepeu 2 horizon or eighth century A.D. This connection is made obvious by the Palmar Orange Polychrome vessels that are adorned by blackpainted, stylized, four-petalled flowers. Although the decorative mode may be consistent, the vessels forms vary widely, and include bowls, cylindrical vases, vases with vertical fluting, and pyriform vases, with or without fluting. Ceramics decorated by this motif have been identified at a number of sites in the area, including Uaxactun, Topoxte, Naranjo (K4379), Tikal, and Xultun (K4388), to name just a few. 

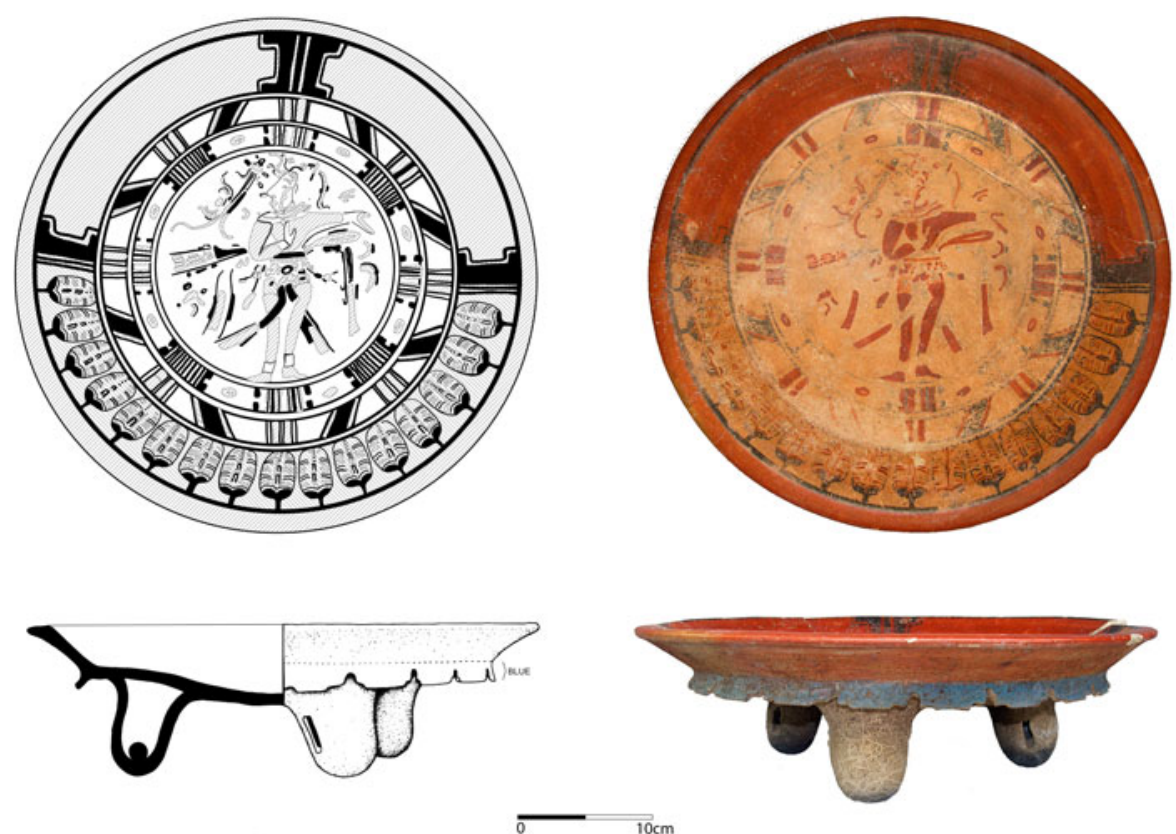

Figure 7. Drawings and photographs of vessel PANC 002 found in Nakum Burial 1 and belonging to the Tikal Dancer style (Saxche Orange Polychrome type). Drawings by Katarzyna Radnicka and photographs by Źrałka.

The two most salient specimens found at Nakum both bear pseudoglyphic texts. One was part of a small bowl with straight and lightly everted sides, with an orange background for the figurative register below, and a cream ground for the upper glyphic register (Figure 10b; vessel PANFC 033). This specimen may be local, or may have been produced at nearby Yaxha, as indicated by the INAA analysis. The other is an orange-slipped globular jar with a constricted orifice and extensive fluting on the exterior (Figure 10a; vessel PANFC 031). It was found broken into

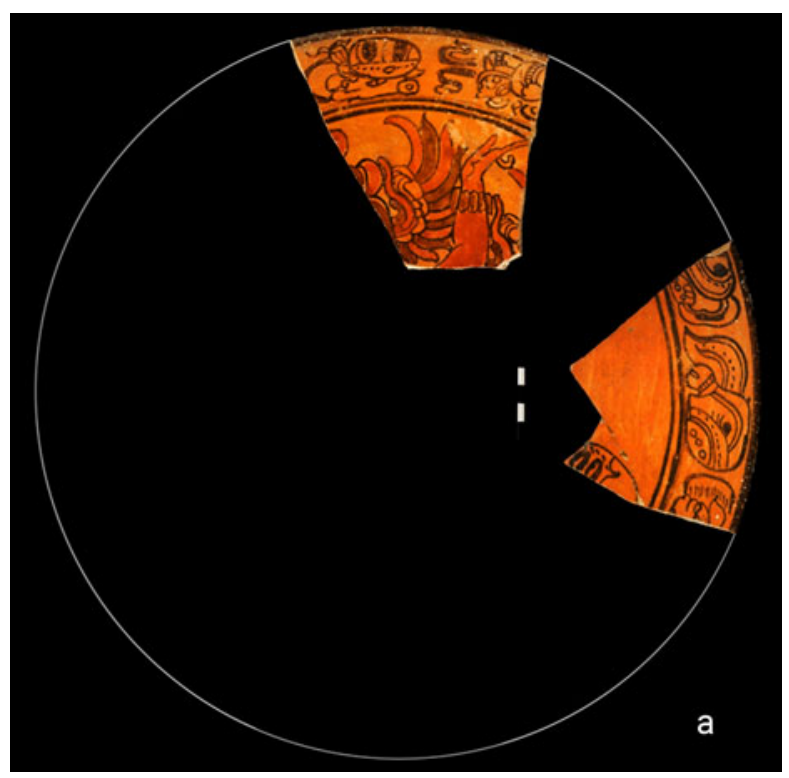

Figure 8. Nakum vessel PANFC 032 revealing stylistic and chemical similarities to the Tikal Dancer plates (Saxche Orange Polychrome type). Photograph by Robert Słaboński. several pieces on the floor of a pyramidal temple (Structure X), and most probably associated with veneration rituals dedicated to the deceased king buried in a tomb constructed below this temple room. This specimen, as indicated by INAA, may have been produced at Naranjo, further testifying to ties between the two sites. Again, petrographic analysis of this sample shows that a volcanic ash-tempered ceramic paste was used (Figure 6b), similar to the one that was used to make the vessel of Holmul Dancer style shown in Figure 5a. The decorations on each of these two specimens are applied in black paint, with red serving to highlight features as well as provide delineations.

\section{THE TERMINAL CLASSIC PERIOD AND MOLDED-CARVED CERAMICS AT NAKUM}

The Terminal Classic period (ca. A.D. 800-900/950) opens up a new chapter in the history of Nakum. The collapse of Classic

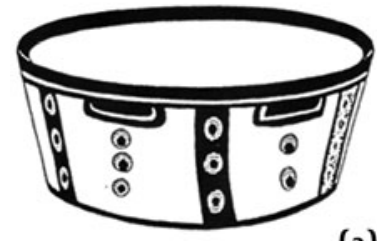

(a)

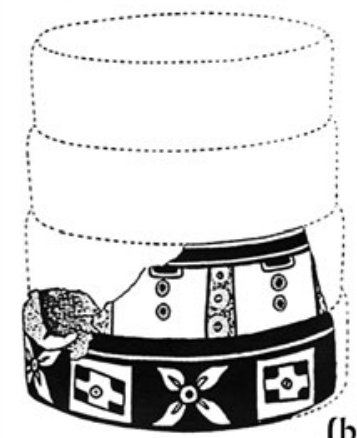

Figure 9. Vessels decorated with the "Dress Shirt" design found at Nakum, Zacatal Cream Polychrome type (after Tozzer 1913:Figures 85-86). 

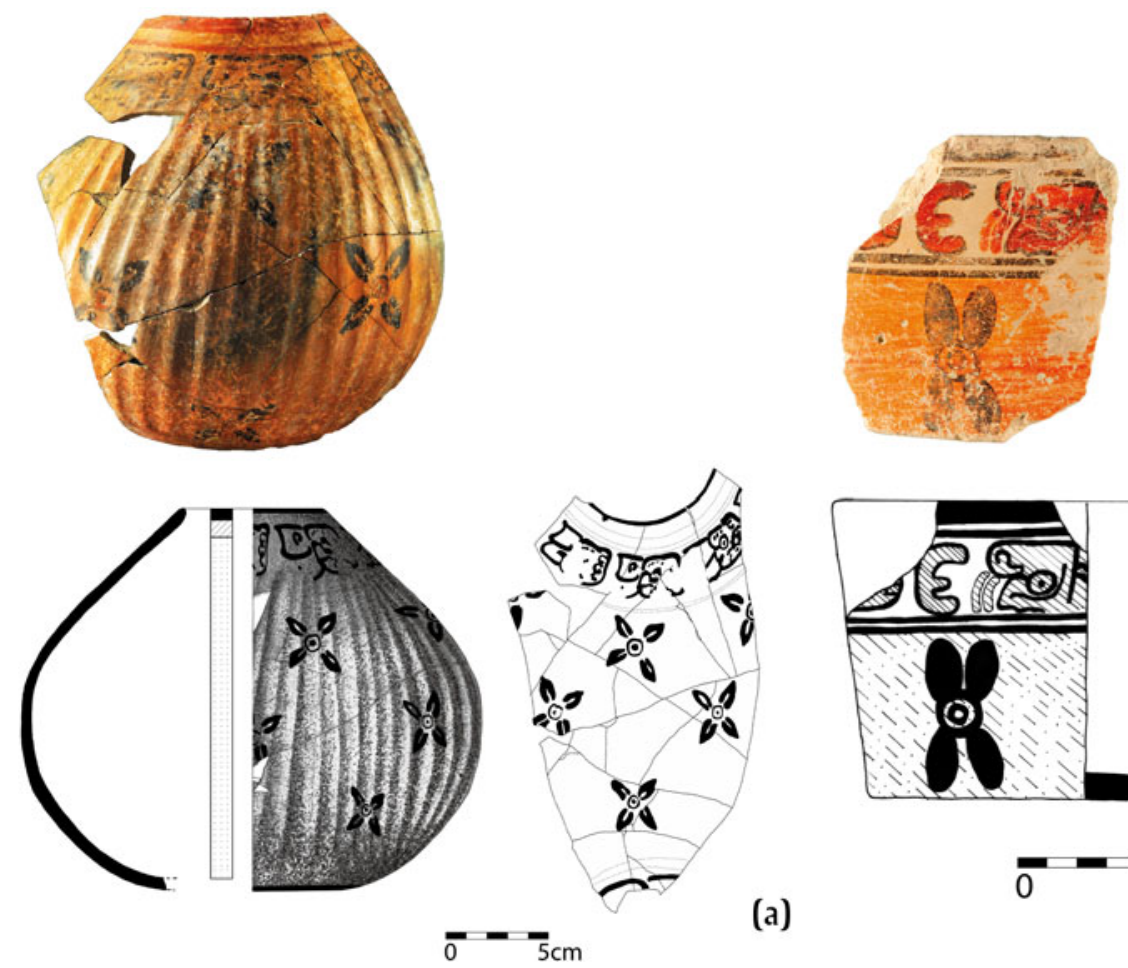

(a)

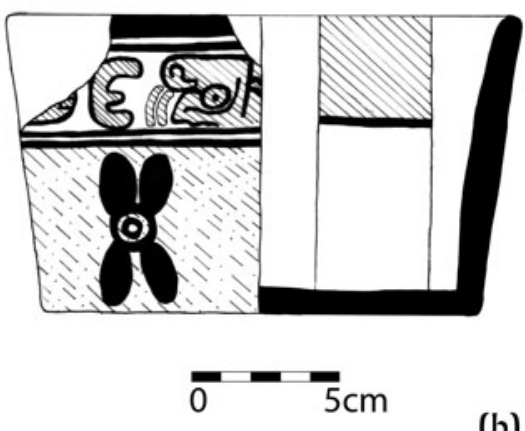

Figure 10. Two Nakum vessels decorated with pseudoglyphs and stylized motif of four-petalled flowers. (a) Vessel PANFC 031 (Granja Central Compuesto). (b) Vessel PANFC 033 (Palmar Orange Polychrome type). Photographs by Robert Słaboński and drawings by Bojkowska.

Maya civilization in the lowlands brings up marked sociopolitical changes, which must have affected political alliances and geopolitical structure, including the existing borders and spheres of influence in the southern Maya lowlands. Large powers, such as Tikal and Naranjo, suffered from demise and power fragmentation. Some smaller polities, however, experienced short-term independence and cultural growth. Nakum elites realized prominent architectural programs and dedicated carved monuments at this juncture. Most of the six stelae documented at Nakum were commissioned during the ninth century A.D. (Helmke et al. 2018; Źrałka et al. 2018). For the first time, we also have evidence of the use at the site of an emblem glyph and other prestigious titles (elk'in kalomte' or "kalomte' of the east"). The latter title may indicate that Nakum elites had some areas located in eastern Peten and western Belize under their political and cultural control, or that they aspired to have such control. These political aspirations toward the end of the Classic period are also seen in the iconography of one of the central Nakum buildings-Structure G, which possibly served as an audiencia - a place of receiving guests by local monarchs. Its façade was embellished with stucco representations of two captives accompanied with glyphs. These sculptures indicate that Nakum lords, for the first time, gained this distinguished privilege to depict captives in public art. One of them is accompanied by a title that can be read as $9 t z u k$ or " 9 province," which may refer to the region of northeastern Peten and neighboring Northern Belize (Helmke et al. 2015:26-28). All these data indicate the changing geopolitical relations in the southern Maya lowlands, which during the Terminal Classic period experienced the shift of borders and spheres of influence, and the rise of new powers.
The Terminal Classic period at Nakum, as well as in other Maya centers, is characterized ceramically by the appearance of new wares, the most remarkable of them being Fine Orange ceramics with characteristic molded-carved vessels, which are treated as markers of this period (Aimers 2004; Bishop 2003; Carter 2014; Foias and Bishop 2005; Helmke and Reents-Budet 2008; Hermes 2019; Sabloff 1973; Smith 1958; Ting and Helmke 2013; Ting et al. 2015). Nakum has in its ceramic assemblage both alleged imported molded-carved ceramics (of the Pabellon Molded-carved type) as well as local imitations represented by the Achote, Azote, Maquina, or Tinaja Groups (Figure 11; Hermes 2019). The iconography of this new category of wares is typically decorated with "confrontation" scenes, similar to many carved monuments of the same epoch (Chase 1983; Graham 1973; Rice and Rice 2004:133; Sabloff 1973).

Apart from small fragments of molded-carved ceramics, the NAP (Nakum Archaeological Project) has also discovered a large fragment of a Sahcaba Molded-carved bowl, found at the southern base of Structure 14 in an ashy matrix midden of Terminal Classic date (PANFC 014; Figure 11a). Associated with this vessel was one radiocarbon sample that returned a date of 2-sigma cal. A.D. 715-940 (1195 \pm 30 BP; GdA-2458/PANMC 130; material dated: carbon). The vessel represents a sitting personage, who holds a spear-thrower in his hand and is accompanied by another character-an elderly person bearing a long staff is shown close to the principal figure. The man is facing towards three glyphic columns on the other side, of which we can discern fragments of another sitting individual.

As for the glyphic columns that evenly divide the iconographic registers, these are pseudoglyphic for the most part. In large 

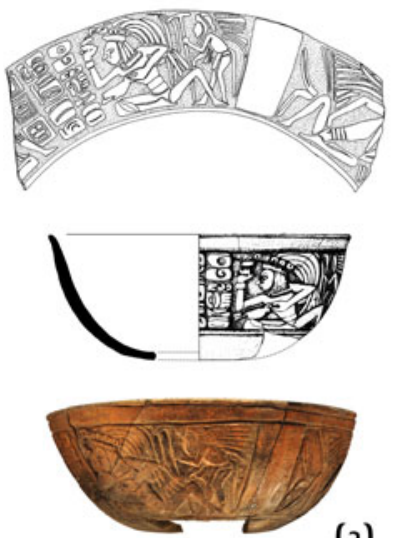

(a)

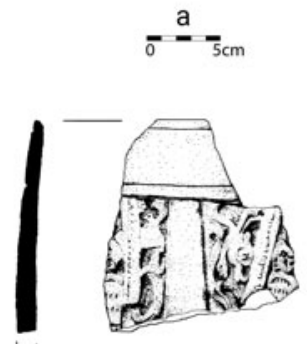

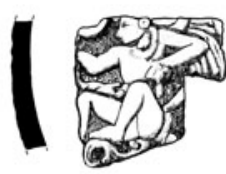

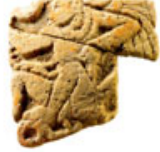

(b)

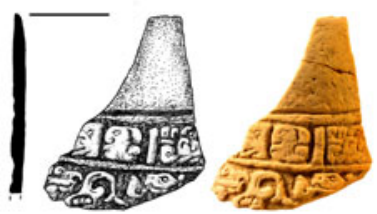

(c)

(d)
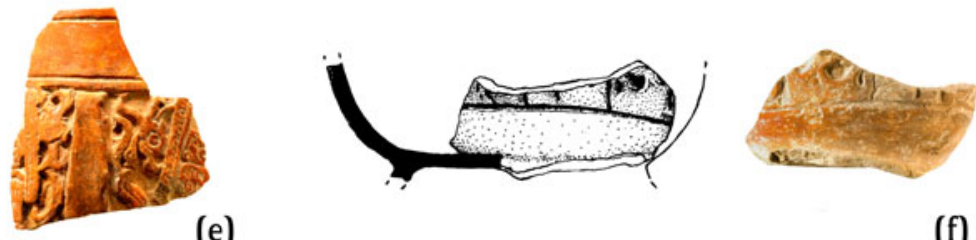

(e)

(f)

Figure 11. (a) Vessel PANFC 014 (Sahcaba Molded-carved). (b-f) Other examples of molded-carved ceramic fragments found at Nakum. Photographs by Robert Słaboński and drawings by Piotr Kołodziejczyk and Bojkowska.

measure, this is a product of the time and of the social segment producing and consuming these vessels, which were nonroyal elites vying for power in the wake of the weakened or failing institution of royalty. Despite the pseudoglyphic nature of the glyphs, some can be discerned as to their origin, including a circular pet sign at the top, a scrolled ja sign lying laterally on its side, and a bow sign, possibly $h i$. What is most significant are the three squared cartouches stacked atop one another in the first column. These are evidently emulations of the squared day signs that begin to appear in the written record of the Maya area during the Terminal Classic period. Salient examples can be found at Seibal (Stelae 3 and 13), Jimbal (Stela 1), and Ucanal (Stela 4). In several of these cases, these squared cartouches are drawn from central Mexican signs or are meant to represent the corresponding day signs of the ritual calendar known as the Tonalpohualli (which is analogous to the Tzolk'in calendar among the Maya). In several cases, these squared cartouches do not appear to record dates, but rather name foreign individuals according to their birthdate, an onomastic practice that was well-established in central Mexico and virtually unknown in the Maya area before A.D. 724 (Colas 2014). As such, these square cartouches would appear to name a group of foreigners, possibly also represented in the imagery of the bowl. This follows the practice seen at other lowland Maya sites, such as Seibal and Chichen Itza, where foreigners are named in associated captions in their own writing system.

There are many other molded-carved fragments found at Nakum dating back to the Terminal Classic period. One of them is identical to a ceramic specimen found at Uaxactun, as noted by Martin (Simon Martin, personal communication 2019). These fragments are so comparable that one may suggest that they were made from the same mold. This need not imply a connection to Uaxactun, however, but rather possible participation in the same greater network wherein such molded-carved ceramics were produced, exchanged, and consumed. Similar examples of Terminal Classic ceramics made from the same molds are attested for El Zotz, Tikal, Uaxactun, and Yaxha (Carter 2014:290-291; Helmke and Reents-Budet 2008).

\section{FINAL CONSIDERATIONS}

We have only a few Classic-period ceramics with glyphic texts that are mostly associated with the Late Classic ceramic complexes dated to ca. A.D. 600-800. The ceramics presented here, however, show that this is a period of intensive interaction between Nakum and its peers, when nonlocal ceramics also appeared at the site. Rather than equating ceramics with people, as has often been done in archaeology as an unconscious heuristic device in interpretative analogy, we do not see these vessels as implying foreign, or even external, presence at Nakum. Instead, we see these particular vessels as singular moments in time, as significant objects that were gifted, traded, bequeathed, and inherited by a very small segment of society to foster bonds of friendship, amity, marriage, and alliances between distinct royal households. Whether the original owners were even present at Nakum is unknown, but these ceramics serve as highly illustrative and tangible proxies of human interactions, conveying not only their proprietorship, but also the heavily charged symbolism that these ceramics display. Rather than serving as a means of reconstructing borders per se, we see a much more fluid system of allegiances wherein discrete settlements emerged as polities during periods of political autonomy. That being said, the ceramics presented above are tangible testimony to the political interactions and patterns of allegiances that Nakum negotiated during the course of the Classic period. 
Based on the present collection, we may make some preliminary attempts to reconstruct the changing fortunes of the history of Nakum. The style of the vessels presented in this paper and the texts that accompany them indicate the existence of complex cultural and perhaps even political bonds between Nakum and other powerful neighbors. Thus, this collection complements our otherwise superficial knowledge about the history of Nakum during the Classic period, which is mainly based on the reading of a few carved monuments. Although our interpretations should be considered as preliminary, it is clear that in the first part of the Late Classic period, Nakum was more oriented politically and culturally toward Naranjo (possibly as its vassal). Nevertheless, during the Tepeu 2 phase (ca. A.D. 700-800), Nakum seems to have fostered stronger ties with Tikal. This possible change in political orientation might have been partly due to the victory of Tikal over Calakmul in A.D. 695, followed by the triumph over its allies, including Naranjo (Martin and Grube 2008:44-45, 49, 78-79). Other evidence of cultural and architectural ties that might have existed during the Tepeu 2 phase between Nakum and Tikal might be also seen in the largest Nakum pyramidal-temples, the relatively slim and soaring Temple $U$ at Nakum (and also the much later Temple C) which is very similar to the famous Tikal temples, especially to Temples I and III.

During the Terminal Classic period, the situation changed dramatically in the region. The demise of the regional powers such as Tikal and Naranjo created a political and cultural vacuum that was partially filled by Nakum and its high political aspirations. Nakum initiated an energetic program of commemorating carved monuments with depictions of local lords using prestigious titles, exchanging ceramics with other important Terminal Classic centers, and realizing large architectural programs (Helmke et al. 2018; Źrałka and Hermes 2012). It seems that the site might have at least partly controlled some territories that once were under the influence of Tikal and Naranjo. This success was short lived, however, for Nakum as a settlement seems to have been almost completely abandoned by the end of the tenth century.

\section{RESUMEN}

Investigaciones recientes llevadas a cabo en el sitio maya Nakum, ubicado en el noreste de Guatemala, han llevado a descubrir una gran colección de artefactos de cerámica. Este importante conjunto, aparte de la cerámica monocromática, incluye fragmentos de vasijas policromas que están decoradas con elaboradas escenas iconográficas y textos jeroglíficos pintados. La mayoría de ellos datan del período clásico tardío (ca. 600-800 d.C.), que representa el florecimiento de la civilización maya precolombina. También hay un grupo de cerámicas interesantes que datan del período clásico terminal (ca. 800-900 d.C.) que en la mayoría de los casos se hicieron con moldes y exhiben contenido glífico o pseudoglífico. El estilo de la cerámica presentada en esta contribución, en complementación por análisis mineralógicos y fisicoquímicos de las muestras de cerámica, indican que Nakum fue parte de una red amplia y compleja de interacciones políticas y económicas entre varios sitios y entidades políticas de las tierras bajas del sur, durante el período clásico. Durante la primera parte del período clásico tardío, parece que Nakum tuvo una estrecha relación con Naranjo, probablemente sirviendo como vasallo al menos desde el reinado de su rey de renombre "Aj Wosal." Varios fragmentos de vasijas encontrados en Nakum parecen haber sido producidos en talleres de cerámica patrocinados por este rey de Naranjo. Después de la victoria de Tikal sobre Naranjo en la primera parte del siglo VIII, Nakum muestra conexiones culturales y políticas más estrechas con Tikal. Sin embargo, hacia el final de la era clásica, cuando observamos el profundo colapso de la civilización maya de las tierras bajas, las élites de Nakum obtienen independencia política de sus antiguos señores. En consecuencia, observamos muchos programas arquitectónicos importantes en Nakum, y la comisión de varios monumentos tallados, que aparecen con prestigiosos títulos y símbolos de poder.

\section{ACKNOWLEDGMENTS}

The preparation of this article was possible thanks to research funded by the National Science Centre $(\mathrm{NCN})$, Poland under the agreement no. UMO-2014/14/E/HS3/00534. We would like to thank Christina Halperin and Carolyn Freiwald for their kind invitation to participate in this Special Section of Ancient Mesoamerica. Thanks are also due to the three anonymous reviewers whose comments significantly benefitted our paper.

\section{REFERENCES}

Aimers, James

2004 Cultural Change on a Temporal and Spatial Frontier: Ceramics of the Terminal Classic to Postclassic Transition in the Upper Belize River Valley. BAR International Series 1325. British Archaeological Reports, Archaeopress, Oxford.

Bishop, Ronald

2003 Five Decades of Maya Fine Orange Ceramic Investigation by INAA. In Patterns and Process: A Festschrift in Honour of Dr. E.V. Sayre, edited by Lambertus van Zelst, pp. 80-91. Smithsonian Center for Materials Research and Education, Suitland.

Blackman, James, and Ronald Bishop

2007 The Smithsonian-nist Partnership: The Application of Instrumental Neutron Activation Analysis to Archaeology. Archaeometry 49:321-341. Boot, Erik

2003 An Annotated Overview of "Tikal Dancer Plates." Electronic document, http://www.mesoweb.com/features/boot/TikalDancerPlates. pdf, accessed February 12, 2019.
Canuto, Marcello, Francisco Estrada-Belli, Thomas G. Garrison, Stephen D. Houston, Mary Jane Acuña, Milan Kováč, Damien Marken, Phillipe Nondédéo, Luke Auld-Thomas, Cyril Castanet, David Chatelain, Carlos R. Chiriboga, Tomáš Drápela, Tibor Lieskovský, Alexandre Tokovinine, Antolín Velasquez, Juan C. Fernández-Díaz, and Ramesh Shrestha

2018 Ancient Lowland Maya Complexity as Revealed by Airborne Laser Scanning of Northern Guatemala. Science 361(6409):eaau0137.

Carr, Robert F., and James E. Hazard

1961 Map of the Ruins of Tikal, El Petén, Guatemala. Tikal Report, No. 11. University Museum, University of Pennsylvania, Philadelphia. Carter, Nicholas

2014 Kingship and Collapse: Inequality and Identity in the Terminal Classic Southern Maya Lowlands. Unpublished Ph.D. dissertation, Department of Anthropology, Brown University, Providence.

Chase, Arlen

1983 Troubled Times: The Archaeology and Iconography of the 
Terminal Classic Southern Lowland Maya. In Fifth Palenque Round Table, 1983, edited by Virginia Fields, pp. 103-114. Pre-Columbian Art Research Institute, San Francisco.

Colas, Pierre Robert

2014 Personal Names: The Creation of Social Status among the Classic Maya. In A Celebration of the Life and Work of Pierre Robert Colas, edited by Christophe Helmke and Frauke Sachse, pp. 19-59. Acta Mesoamericana, Vol. 27. Verlag Anton Saurwein, Munich.

Culbert, T. Patrick

1993 The Ceramics of Tikal: Vessels from the Burials, Caches, and Problematical Deposits. Tikal Report, No. 25A. University Museum, University of Pennsylvania, Philadelphia.

Culbert, T. Patrick, Vilma Fialko, Brian McKee, Liwy Grazioso, Julie

Kunen, and Leonel Paez

1997 Investigaciones arqueológicas en el bajo La Justa, Petén. In $X$ Simposio de Investigaciones Arqueológicas en Guatemala, 1996, edited by Juan Pedro Laporte and Héctor Escobedo, pp. 367-371. Museo Nacional de Arqueología y Etnología, Guatemala City.

Demarest, Arthur A., Matt O’Mansky, Claudia Wolley, Dirk Van

Tuerenhout, Takeshi Inomata, Joel Palka, and Héctor Escobedo

1997 Classic Maya Defensive Systems and Warfare in the Petexbatun Region: Archaeological Evidence and Interpretations. Ancient Mesoamerica 8:229-253.

Estrada-Belli, Francisco

2018 Resumen de investigaciones arqueológicas y conservación de arquitectura monumental en la región de Holmul. Temporada 2018. In Investigaciones arqueológicas y conservación de arquitectura monumental en la región de Holmul. Temporada 2018, edited by Francisco Estrada-Belli, pp. 1-33. Unpublished report submitted to Departamento de Monumentos Prehispánicos y Coloniales de la Dirección General del Patrimonio Cultural y Natural Ministerio de Cultura y Deportes de Guatemala, Guatemala City.

Estrada-Belli, Francisco, and Alexandre Tokovinine

2016 A King's Apotheosis: Iconography, Text, and Politics from a Classic Maya Temple at Holmul. Latin American Antiquity 27: 149-168.

Fialko, Vilma

2005 Ten Years of Archaeological Investigations at the Holmul River Basin in the Northeastern Region of Peten. English version of paper presented during XVIII Simposio de Investigaciones Arqueológicas en Guatemala. Electronic document, www.famsi.org/reports/03101/ 19fialko/19fialko.pdf, accessed November 13, 2019.

Foias, Antonia, and Ronald Bishop

2005 Fine Paste Wares and the Terminal Classic in the Petexbatun and Pasión Regions, Peten, Guatemala. In Geographies of Power: Understanding the Nature of Terminal Classic Pottery in the Maya Lowlands, edited by Sandra López Varela and Antonia Foias, pp. 23-40. BAR International Series 1447. British Archaeological Reports, Archaeopress, Oxford.

Garrison, Thomas, Stephen Houston, and Omar Alcover Firpi

2019 Recentering the Rural: Lidar and Articulated Landscapes Among the Maya. Journal of Anthropological Archaeology 53:133-146.

Graham, John

1973 Aspects of Non-Classic Presences in the Inscriptions and Sculptural Art of Seibal. In The Classic Maya Collapse, edited by Patrick Culbert, pp. 207-217. School for Advanced Research, University of New Mexico Press, Albuquerque.

\section{Grube, Nikolai}

2000 Monumentos esculpidos e inscripciones jeroglíficas en el triángulo Yaxhá-Nakum-Naranjo. In El sitio maya de Topoxte: investigaciones en una isla del lago Yaxhá, Petén, Guatemala, edited by Wolfgang Wurster, pp. 249-268. Philipp von Zabern, Mainz am Rhein.

Haviland, William

1981 Dower Houses and Minor Centers at Tikal, Guatemala: An Investigation into the Identification of Valid Units in Settlement Hierarchies. In Lowland Maya Settlement Patterns, edited by Wendy Ashmore, pp. 89-117. University of New Mexico Press, Albuquerque. Helmke, Christophe

2019 An Analysis of the Imagery and Text of the Cuychen Vase. In The Realm Below: Speleoarchaeological Investigations in the Macal River Valley, Belize, edited by Christophe Helmke, pp. 122-159. Precolumbia Mesoweb Press, San Francisco.
Helmke, Christophe, Claire E. Ebert, Jaime J. Awe, and Julie A. Hoggarth 2019a The Lay of the Land: A Political Geography of an Ancient Maya Kingdom in West-Central Belize. Contributions in New World Archaeology 12:9-54.

Helmke, Christophe, and Dorie Reents-Budet

2008 A Terminal Classic Moulded-Carved Ceramic Type of the Eastern Maya Lowlands. Research Reports in Belizean Archaeology 5:37-49.

Helmke, Christophe, Gail Hammond, Thomas Guderjan, Pieta Greaves, and Colleen Hanratty

2019b Sighting a Royal Vehicle: Observations on the Graffiti of Tulix Mul, Belize. The PARI Journal 19:10-30.

Helmke, Christophe, and Jaime J. Awe

2008 Organización territorial de los antiguos mayas de Belice Central: Confluencia de datos arqueológicos y epigráficos. Mayab 20:65-91.

Helmke, Christophe, Jaime J. Awe, Shawn G. Morton, and Gyles Iannone 2015 The Text and Context of the Cuychen Vase, Macal Valley, Belize. Maya Archaeology 3:8-29.

Helmke, Christophe, Simon Martin, Jarosław Źrałka, Bolesław Zych,

Wiesław Koszkul, Magdalena Rusek, and Juan Luis Velásquez

2018 Los monumentos monolíticos de Nakum, Guatemala. In XXXI Simposio de Investigaciones Arqueológicas en Guatemala, 2017, edited by Bárbara Arroyo, Luis Méndez, and Gloria Ajú, pp. 851-866. Museo de Arqueología y Etnología de Guatemala, Guatemala City.

Helmke, Christophe, Yuriy Polyukhovych, Dorie J. Reents-Budet, and

Ronald L. Bishop

2017 A Bowl Fit for a King: A Ceramic Vessel of the Naranjo Court Bearing the Komkom Emblem Glyph. The PARI Journal 18:9-24.

Hermes, Bernard

2000 Industria cerámica. In El sitio maya de Topoxte: Investigaciones en una isla del lago Yaxhá, Petén, Guatemala, edited by Wolfgang Wurster, pp. 164-202. Philipp von Zabern, Mainz am Rhein.

2019 La cerámica del sitio maya Nakum, Petén, Guatemala. Jagiellonian University Press, Cracow.

Houston, Stephen D., David Stuart, and Karl A. Taube

1992 Image and Text on the "Jauncy Vase." In The Maya Vase Book, Volume 3, edited by Justin Kerr, pp. 498-512. Kerr Associates, New York. Kerr, Justin

2019 Maya Vase Database. Electronic document, http: / research.mayavase.com/kerrmaya.html, accessed January 10, 2020.

Koszkul, Wiesław, Bernard Hermes, and Zoila Calderón

2006 Teotihuacan-related Finds from the Maya Site of Nakum, Peten, Guatemala. Mexicon 28:117-127.

Kunen, Julie L., Patrick Culbert, Vilma Fialko, Brian R. McKee, and Liwy Grazioso

2000 Bajo Communities: A Case Study from the Central Peten. Culture and Agriculture 22:15-31.

Luin, Camilo, Dmitri Beliaev, Filipp Galeev, and Sergey Vepretskiy

2018 Las inscripciones jeroglíficas del Museo VICAL, Casa Santo Domingo. In XXXI Simposio de Investigaciones Arqueológicas en Guatemala, 2017, edited by Barbara Arroyo, Luis Méndez, and Gloria Ajú, pp. 877-886. Museo de Arqueología y Etnología de Guatemala, Guatemala City.

Martin, Simon, and Nikolai Grube

2008 Chronicle of the Maya Kings and Queens: Deciphering the Dynasties of the Ancient Maya. 2nd ed. Thames and Hudson, London.

Puleston, Dennis E., and Donald W. Callender, Jr.

1967 Defensive Earthworks at Tikal. Expedition 9:40-48.

Rand, Asta, Varinia Matute, Vaughan Grimes, Carolyn Freiwald, and Jarosław Źrałka

2020 Prehispanic Maya Diet and Migration at Nakum, Guatemala: A Multi-Isotopic Approach. Journal of Archaeological Science: Reports 32:102374.

Reents-Budet, Dorie, Ellen E. Bell, Loa P. Traxler, and Ronald L. Bishop 2004 Early Classic Ceramic Offerings at Copan: A Comparison of the Hunal, Margarita, and Sub-Jaguar Tombs. In Understanding Early Classic Copan, edited by Ellen Bell, Marcello Canuto, and Robert Sharer, pp. 159-190. University of Pennsylvania Museum of Archaeology and Anthropology, Philadelphia.

Reents-Budet, Dorie J.

1991 The "Holmul Dancer" Theme in Maya Art. In Sixth Palenque Round Table, 1986, edited by Virginia M. Fields, pp. 217-222. University of Oklahoma Press, Norman.

1994 Painting the Maya Universe: Royal Ceramics of the Classic Period. Duke University Press, Durham. 
Rice, Prudence M., and Don S. Rice

2004 Late Classic to Postclassic Transformations in the Petén Lakes Region, Guatemala. In The Terminal Classic in the Maya Lowlands. Collapse, Transition, and Transformation, edited by Arthur A. Demarest, Prudence M. Rice, and Don S. Rice, pp. 125-140. University Press of Colorado, Boulder.

Sabloff, Jeremy

1973 Continuity and Disruption during Terminal Late Classic Times at Seibal: Ceramic and Other Evidence. In The Classic Maya Collapse, edited by Patrick Culbert, pp. 107-133. School for Advanced Research, University of New Mexico Press, Albuquerque.

Scherer, Andrew K., and Charles Golden

2009 Tecolote, Guatemala: Archaeological Evidence for a Fortified Late Classic Maya Political Border. Journal of Field Archaeology 34: 285-305.

Smith, Robert

1958 The Place of Fine Orange Pottery in Mesoamerican Archaeology. American Antiquity 24:151-160.

Stuart, David

2000 The "Arrival of Strangers": Teotihuacan and Tollan in Classic Maya History. In Mesoamerica's Classic Heritage: From Teotihuacan to the Aztecs, edited by David Carrasco, Lindsay Jones, and Scott Sessions, pp. 465-514. University Press of Colorado, Boulder.

Taschek, Jennifer, and Joseph Ball

1992 Lord Smoke-Squirrel's Cacao Cup: The Archaeological Context and Socio-Historical Significance of the Buenavista 'Jauncy Vase.' In The Maya Vase Book, Volume 3, edited by Justin Kerr, pp. 490-498. Kerr Associates, New York.

Ting, Carmen, and Christophe Helmke

2013 Technology, Production, and Distribution of Terminal Classic Molded-Carved Vases in the Central Maya Lowlands. Open Journal of Archaeometry 1:43-48.

Ting, Carmen, Marcos Martinón-Torres, Elizabeth Graham, and Christophe Helmke

2015 The Production and Exchange of Moulded-Carved Ceramics and the 'Maya Collapse.' Journal of Archaeological Science 62:15-26.
Tokovinine, Aleksandre, and Vilma Fialko

2019 En el cerro de los colibríes: el patrón divino y el paisaje sagrado de la ciudad de Naranjo. In XXXII Simposio de Investigaciones Arqueológicas en Guatemala, 2019, edited by Barbara Arroyo, Luis Méndez, and Gloria Ajú, pp. 825-838. Museo Nacional de Arqueología y Etnología, Guatemala City.

Tokovinine, Alexandre

2016 "It is his Image with Pulque": Drinks, Gifts, and Political Networking in Classic Maya Texts and Images. Ancient Mesoamerica 27:13-29.

Tozzer, Alfred

1913 A Preliminary Study of the Prehistoric Ruins of Nakum, Guatemala. Memoirs of the Peabody Museum of Archaeology and Ethnology, Vol. 3. Peabody Museum of Archaeology and Ethnology, Harvard University, Cambridge.

Trigger, Bruce G.

2003 Understanding Early Civilizations: A Comparative Study. Cambridge University Press, Cambridge.

Webster, David, Timothy Murtha, Kirk D. Straight, Jay Silverstein, Horacio

Martinez, Richard E. Terry, and Richard Burnett

2007 The Great Tikal Earthwork Revisited. Journal of Field Archaeology 32:41-64.

Źrałka, Jarosław, and Bernard Hermes

2012 Great Development in Troubled Times: Terminal Classic at Nakum, Peten, Guatemala. Ancient Mesoamerica 23:161-187.

Źrałka, Jarosław, Christophe Helmke, Simon Martin, Wiesław Koszkul, and Juan Luis Velásquez

2018 Monolithic Monuments of Nakum, Guatemala. The PARI Journal 19:1-28.

Źrałka, Jarosław, and Wiesław Koszkul

2015 Archaeological Evidence for Ancient Maya Water Management: The Case of Nakum, Petén, Guatemala. Antiquity 89: 397-416.

Źrałka, Jarosław, Wiesław Koszkul, Simon Martin, and Bernard Hermes

2011 In the Path of the Maize God: A Royal Tomb at Nakum, Petén, Guatemala. Antiquity 85:890-908. 